\title{
Evaluation of physicochemical properties and in-vitro release profile of glipizide-matrix patch
}

\author{
Kajal Ghosal*, Rajan Rajabalaya, Anindya Kishore Maiti, \\ Bikramaditya Chowdhury, Arunabha Nanda
}

Department of Pharmaceutical Technology, Jadavpur University, India

\begin{abstract}
Objectives - The aim of the present investigation was to form matrix patches with ethyl cellulose (EC) as the base polymer, polyvinyl pyrrolidone (PVP) as the copolymer, plasticizer with dibutyl phthalate (DBP) or acetyl tributyl citrate (ATBC) and the drug glipizide (gz) by the solvent casting method. Physicochemical properties of the patches and in vitro drug release were determined in a modified Keshary-chien diffusion cell to optimize the patch formulations with the help of experimental data and figures for further studies. Techniques - EC and PVP of different proportions with different weight percentages of either DBP or ATBC and a fixed amount of glipizide were taken for matrix patch formations. The dried patches were used for measuring their drug contents as well as their thicknesses, tensile strengths, moisture contents and water absorption amounts in percentage. In vitro release amounts at different intervals were measured by UVspectrophotometer. Results - Drug contents varied from 96-99\%. Thickness and tensile strength varied due to weight variation of the ingredients in the matrix patches. Moisture content and water absorption in wt $\%$ were greater for the patches containing higher amount of PVP due to its hydrophilic nature. Variations in drug release were observed among various formulations. It was found that all of the releases followed diffusion controlled zero order kinetics. Two DBP patches yielded better and more adequate release. Conclusions The two formulations with DBP were the preferred choice for making matrix patches for further studies.
\end{abstract}

Uniterms: Glipizide/physicochemical properties. Glipizide/in-vitro release. Ethyl cellulose. Polyvinyl pyrrolidone. Plasticizer.

O objetivo da presente pesquisa foi formar matrizes para bandagens de liberação transdérmica com etilcelulose (EC) como polímero base, polivinilpirrolidona (PVP), como copolímero, plastificante com ftalato de dibutila (DBP) ou citrato de tributilacetila (ATBC) e o fármaco glipizida (gz) pelo método de evaporação do solvente (moldagem com solvente). As propriedades físico-químicas das bandagens e a liberação do fármaco in vitro na célula de difusão de Keshary-chien modificada foram determinadas para aperfeiçoar as formulações das bandagens com o auxílio de dados experimentais e figuras para estudos posteriores. EC e PVP em diferentes proporções com porcentagens diferentes de massa tanto de DBP quanto de ATBC e quantidade fixa de glipizida foram utilizadas como matrizes para a formação de bandagens de liberação transdérmica. As bandagens secas foram empregadas para medir seus conteúdos em fármaco e, também, a sua espessura, resistência à tensão, conteúdos de umidade e porcentagem de absorção de água. As quantidades liberadas in vitro em diferentes intervalos de tempo foram medidas por espectrofotômetro de UV. Os conteúdos de fármaco variaram de 96 a 99\%. A espessura e a resistência à ruptura variaram devido à variação de massa dos componentes da matriz das bandagens. O conteúdo de umidade e a água absorvida, em porcentagem de massa, foram maiores para as bandagens que continham grandes quantidades de PVP devido à sua natureza hidrofílica. As variações na liberação de fármaco foram observadas entre as várias formulações. Todas as liberações seguiram a cinética de difusão controlada de ordem zero. Duas bandagens DBP resultaram em melhor e mais adequada liberação. As duas formulações com DBP foram escolhidas para a preparação de matriz de bandagens para estudos posteriores.

Unitermos: Glipizida/propriedades físico-químicas. Glipizida/liberação in vitro. Etil celulose. Polivinil pirrolidona. Plastificante.

\footnotetext{
"Correspondence: K. Ghosal. Department of Pharmaceutical Technology, Jadavpur University. Raja S. C. Mullick Road, Kolkata - 700 032, West Bengal

- India. E-mail:kaju_3_ju@rediffmail.com.
} 


\section{INTRODUCTION}

Diabetes mellitus is a major and growing health problem worldwide and an important cause of prolonged ill health and early death (Arunachalam, Gunasekaran, 2002). It is a chronic metabolic disorder characterized by a high blood glucose concentration (hyperglycemia) caused by insulin deficiency and it is often combined with insulin resistance (Davis, Granner, 1996; Nolte, Karam, 2003). Glipizide is an oral blood-glucose-lowering drug of the sulfonylurea class. Glipizide has been in extensive use to treat NIDDM and acts by increasing the release of endogenous insulin as well as its peripheral effectiveness. It has been associated with severe and sometimes fatal hypoglycemia and gastric disturbances such as nausea, vomiting, heartburn, anorexia and increased appetite after oral therapy. Since these drugs are usually intended to be taken for a long period, patient compliance is also very important. Transdermal delivery has many advantages over the oral route of drug administration; it avoids hepatic first pass metabolism, termination of further administration, long term duration, potentially decreases side effects and improves patient compliance. Therefore, an attempt was made to formulate transdermal glipizide patches (Bennette et al., 2005; Mutalik, Udupa, 2002; Mutalik, Udupa, 2003; Mutalik, Udupa, 2004; Mutalik, Udupa, 2005; Mutalik, Udupa, 2006; Mutalik et al., 2006) which can reduce frequency of dosing and some of the complications of higher dose oral therapy. There is also the feasibility of transdermal delivery of glipizide to consider. Glipizide (molecular weight 445.5 Da) shows a favourable partition coefficient (log octanol/ buffer: $0.28 \pm 0.12$ ) and negligible skin degradation. The present research work was carried out with two different plasticizers of two different weight proportions using EC as a main polymer and PVP as a co-polymer. Different physicochemical properties of these matrix patches were studied. An in vitro model for the release of glipizide from matrix patches was carried out to study the effect of copolymer and plasticizers.

\section{MATERIALS AND METHODS}

Glipizide (BP grade) was kindly donated by Sun Pharma, Dadra, India. Ethyl cellulose (N 22) was gifted from Pharma- Signet Chemical Corporation, Mumbai, India. Polyvinyl pyrrolidone (K-30) was obtained from SRL Pvt. Ltd., Mumbai, India. DBP was purchased from Qualigens Fine Chemicals, India. ATBC was gifted by Morflex, USA. All other chemicals used in the study were of analytical grade.

\section{Analytical method}

A total of $100 \mathrm{mg}$ of glipizide was accurately weighed, placed in a $100 \mathrm{~mL}$ volumetric flask and dissolved in methanol. $10 \mathrm{~mL}$ of this solution was taken in a $100 \mathrm{~mL}$ volumetric flask. In order to generate a calibration curve, 2 to $30 \mu \mathrm{g} / \mathrm{mL}$ of primary standard were prepared and the calibration curve was obtained by measuring their absorbance at predetermined UV- VIS spectrophotometer at $275 \mathrm{~nm}$. The concentration of glipizide was calculated using the linear regression equation of the calibration curve (Absorbance $=0.0236 \times$ concentration +0.0149 , $\left.\mathrm{r}^{2}=0.9959\right)$. When a standard drug solution was assayed repeatedly $(n=6)$, mean standard error (accuracy) and RSD (precision) were found to be $0.3 \%$ and $0.5 \%$, respectively.

\section{Preparation of transdermal patches}

For preparation of the patches, $300 \mathrm{mg}$ of EC was dissolved in $5 \mathrm{~mL}$ chloroform followed by the addition of 50 - $200 \mathrm{mg}$ of PVP by stirring the total mass with a magnetic stirrer. Subsequently, $15 \mathrm{mg}$ of gz and the plasticizer, either DBP or ATBC (each $20-30 \%$ of the total weight of EC and PVP), were added with stirred mass. The total mass was then slowly poured into the center of SS rings having a backing layer of aluminum foil. The total mass was dried at room temperature for $24 \mathrm{~h}$ (Kulkarni et al., 2002; Munden et al., 1964). The dried patches were taken in a plastic seal bag and stored in desiccators. The patch characteristics are presented in Table I.

TABLE I - Patch combination

\begin{tabular}{lccccc}
\hline Patch code & $\begin{array}{c}\text { EC } \\
(\mathbf{m g})\end{array}$ & $\begin{array}{c}\text { PVP } \\
(\mathbf{m g})\end{array}$ & $\begin{array}{c}\text { Glipizide } \\
(\mathbf{m g})\end{array}$ & $\begin{array}{c}\text { DBP } \\
(\mathbf{\%})\end{array}$ & $\begin{array}{c}\text { ATBC } \\
(\mathbf{\%})\end{array}$ \\
\hline F1 & 300 & 200 & 15 & 20 & \\
F2 & 300 & 150 & 15 & 20 & \\
F3 & 300 & 200 & 15 & & 20 \\
F4 & 300 & 150 & 15 & & 20 \\
F5 & 300 & 200 & 15 & 30 & \\
F6 & 300 & 150 & 15 & 30 & \\
F7 & 300 & 100 & 15 & 30 & \\
F8 & 300 & 50 & 15 & 30 & \\
F9 & 300 & 200 & 15 & - & 30 \\
F10 & 300 & 150 & 15 & - & 30 \\
\hline
\end{tabular}

\section{Drug content}

A small circular known area from each patch was cut, weighed accurately, dissolved in $2 \mathrm{~mL}$ casting solvent, and the volume diluted with a known amount of distilled water to measure the total amount of drug content present 
in the area by UV-VIS spectrophotometer at $275 \mathrm{~nm}$. This yields the actual amount of drug present. The theoretical amount is calculated using the equation:

[(15 mg of drug $\times$ small cut piece area $) /$ total area of the patch].

The percentage ratio between actual amount and theoretical amount gives the drug content in percentage. Six similar readings from six patches of the same composition were determined and an average with standard deviation (SD) is shown in Table II.

\section{Determination of patch thickness}

The thickness of a patch was measured by a digital micrometer (Mitutoyo, Japan). Six samples of each formulation were taken and measurements were made. Average thickness is shown in Table II.

\section{Determination of tensile strength}

The tensile strength of the patch was evaluated using an Instron 4204, UK tensilometer with a mounted load of $50 \mathrm{KN}$. Six samples of each formulation were tested with an extension speed of $5 \mathrm{~mm} / \mathrm{m}$ [American Society for Testing Materials(ASTM); method D 882- 75D]. The test was carried out at $25 \pm 2{ }^{\circ} \mathrm{C}$ and $56 \% \pm 2 \% \mathrm{RH}$. The tensile strength was calculated from the equation,

$\tau=L_{\max } / A_{i}$

Where $\tau$ is the tensile strength; $L_{\max }$ is the maximum load and $A_{i}$ is the initial cross sectional area of the sample. An average value is shown in Table II.

\section{Moisture content}

Three patches of the same composition were wei- ghed individually and kept in a dessicator containing fused calcium chloride at $40^{\circ} \mathrm{C}$ for $24 \mathrm{~h}$ (Mukherjee et al. 2005a). The patches were then reweighed until a constant weight was obtained. The moisture content of a patch was calculated as a percentage based on the difference between the initial and constant final weight of the patch. An average is shown in Table II.

\section{Water absorption studies}

To determine the water absorption capacity of the patches, three weighed patches of the same composition were kept at room temperature for $24 \mathrm{~h}$ and exposed to two relative humidities of $75 \%$ (a saturated solution of sodium chloride) and 93\% (a saturated solution of ammonium hydrogen phosphate) in different desiccators at room temperature (Mukherjee et al. 2005b). The water absorption capacity of the patches was determined as the percentage increase in the weight of the patch divided by its initial weight. The weights were periodically recorded until a constant weight was obtained. An average was recorded (Table II).

\section{In vitro release studies}

The In vitro release studies were carried out in a modified Keshary-chien diffusion cell. A piece of matrix patch (circular, $2.5 \mathrm{~cm}$ diameter) was mounted carefully on the donor compartment. The donor compartment was empty and the backing membrane side of the matrix patch was open to the atmosphere while the receptor compartment was filled with freshly prepared phosphate buffer saline $\mathrm{pH}$ 7.4. Outside the receptor compartment, water from a constant temperature bath flowed continuously through the jacket at $37 \pm 0.5^{\circ} \mathrm{c}$. The receptor liquid was slowly stirred by magnetic stirrer at $40-50 \mathrm{rpm}$. The temperature in the release/permeation area was maintained at $37 \pm 0.5^{\circ} \mathrm{C}$. The

TABLE II - Patch characteristics

\begin{tabular}{lcccccc}
\hline Patch code & $\begin{array}{c}\text { \%Glipizide content } \\
(\text { Avg } \pm \text { SD })\end{array}$ & $\begin{array}{c}\text { Patch } \\
\text { Tensile strength } \\
\left(\mathrm{N} / \mathbf{m m}^{2}\right)\end{array}$ & $\begin{array}{c}\text { Patch thickness } \\
(\mu \mathrm{m})\end{array}$ & $\begin{array}{c}\text { Moisture } \\
\text { content } \\
(\mathrm{Wt} \%)\end{array}$ & \multicolumn{2}{c}{$\begin{array}{c}\text { Water absorption } \\
\text { (Wt \%) }\end{array}$} \\
\hline F5 & $97 \pm 6.52$ & 11.489 & 182 & 1.20 & 3.40 & 3.80 \\
F6 & $98 \pm 5.52$ & 13.675 & 172 & 1.13 & 2.42 & 2.98 \\
F7 & $99 \pm 5.56$ & 7.705 & 135 & 1.07 & 2.38 & 2.72 \\
F8 & $99 \pm 4.52$ & 7.383 & 116 & 1.00 & 1.61 & 2.04 \\
F9 & $96.65 \pm 6.50$ & 11.800 & 190 & 1.21 & 3.60 & 4.00 \\
F10 & $96 \pm 6.10$ & 14.200 & 187 & 1.14 & 2.54 & 2.64 \\
\hline
\end{tabular}

Notations: Avg: Average; SD: Standard deviation; 75\% RH and 93\% RH: 75\% relative humidity and 93\% relative humidity, respectively. 
volume of the receptor liquid $(53 \mathrm{~mL})$ was such that the piece of the matrix patch (drug side) just touches the receptor liquid surface horizontally for molecular diffusion. Samples $(2 \mathrm{~mL})$ were withdrawn at $1 \mathrm{hr}$ intervals up to $8 \mathrm{~h}$ and replaced immediately with the same volume of saline solution. Samples were analyzed by UV at $275 \mathrm{~nm}$ after suitable dilution. Release parameters are given in Table III.

\section{Data and statistical analysis}

The steady state release rate $\left(\mu \mathrm{g} / \mathrm{cm}^{2} / \mathrm{h}\right)$ was calculated from the slope of the linear plot of the cumulative amount released per unit area $\left(\mu \mathrm{g} / \mathrm{cm}^{2}\right)$ as a function of time $(\mathrm{t}, \mathrm{h})$.

Data are presented as mean \pm standard deviation (SD). Statistical comparisons were made using Student's $\mathrm{t}$-test at a significance level of $\mathrm{p}<0.05$ using MS-excel software.

\section{RESULTS AND DISCUSSION}

DBP and ATBC were used as plasticizers to prepare the patches. The tensile strength of only the patches containing $30 \%$ DBP or $30 \%$ ATBC as plasticizer was measured. Other patches containing $20 \%$ of plasticizer were discarded as they are brittle in nature (as in the case of F1, F2, F3 and F4). From Table II, it is clear that patches containing ATBC have greater tensile strength compared to those with DBP. Plasticizer embeds between the chains of polymers, spacing them apart and making the polymeric patch more flexible. Therefore, the presence of higher molecular weight ATBC increases the tensile strength of the polymeric patches. Thus, the tensile strength of patch F9 was greater than that of F5 while the tensile strength of patch F10 was greater than that of F6. Moreover, a PVP increase in DBP patches increases the tensile strength (thus tensile strength of F6 $>$ tensile strength of F7 $>$ tensile strength of F8). Addition of higher amounts of PVP reduces the matrix tensile strength. Thus, the tensile strength of F5 was less than that of F6 (Mosquera, 1997). Thickness of the patches containing ATBC was slightly greater than that of DBP patches. However, the moisture content and water absorption capacity of ATBC patches is more or less the same as the DBP patch. As the amount of PVP increases, thickness as well as moisture content and water absorption capacity of the DBP and ATBC patches at different humidities increases. The hydrophilic nature of PVP has to be taken into account with regard to their higher moisture content and higher water absorption capacity.

\section{In vitro drug release studies}

Release of a drug from a transdermal drug delivery system mainly involves diffusion factors (Tojo et al., 1985). One such factor is the amount of hydrophilic polymer. As the amount of hydrophilic polymer (PVP) increases, dissolution of more and more PVP in the diffusion medium forms pores which increase the rate of diffusion. However, excess amounts of PVP will produce such a high viscosity that drug diffusion through the patch may be hampered. From Table III, it is clear that when the ratio of EC and PVP is 2:1 (F6) maximum release of glipizide occurs along with maximum release rate compared to the higher ratios present in $\mathrm{F} 7$ and F8. In the case of F5, where the ratio is lower (1.5:1), both the parameters reduce appreciably, probably due to the deposition of excess PVP in diffusion rivulets in the matrix patch. The patch $\mathrm{F} 8$ having the ratio $6: 1$ provided $27.4 \%$ cumulative release at $8 \mathrm{~h}$ whereas $\mathrm{F} 7$ (ratio $3: 1$ ) and F6 (2:1) yielded $42.81 \%$ cumulative release and $70.21 \%$ cumulative release at $8 \mathrm{~h}$, respectively. Due to deposition of excess PVP in diffusion rivulets, F5 provided a lower percentage of cumulative release at $8 \mathrm{~h}(65.41 \%)$. The patches containing ATBC provided a lower percentage of drug release than the DBP patch. F9 and F10 yielded $46.58 \%$ cumulative release and $44.86 \%$ cumulative release, respectively. This is due to the fact that higher molecular weight ATBC was embedding between the polymeric chains and hampering drug release, although F9 and F10 patches had the same

TABLE III - Release parameters of glipizide from various patches

\begin{tabular}{lccccr}
\hline $\begin{array}{l}\text { Patch } \\
\text { Code }\end{array}$ & $\begin{array}{c}\text { Cumulative amount } \\
\text { of release at } 8 \mathrm{~h} \\
\left(\mu \mathrm{g} / \mathrm{cm}^{2}\right)\end{array}$ & $\begin{array}{c}\text { Release } \\
\text { rate } \\
\left(\mu \mathrm{g} / \mathrm{cm}^{2} / \mathrm{h}\right)\end{array}$ & $\begin{array}{c}\text { Cumulative amount } \\
\text { of } \% \text { release } \\
\text { at } 8 \mathrm{~h}(\%)\end{array}$ & $\begin{array}{c}\text { Best fit regression equation } \\
\text { for release plot }\end{array}$ & $\mathrm{r}^{2}$ \\
\hline F5 & $335 \pm 24$ & 39.107 & 65.41 & $\mathrm{Q}=39.107 \mathrm{X}+17.143$ & 0.9928 \\
F6 & $410 \pm 29$ & 50.06 & 70.21 & $\mathrm{Q}=50.06 \mathrm{X}+21.607$ & 0.9968 \\
F7 & $281 \pm 18$ & 20.616 & 42.81 & $\mathrm{Q}=20.616 \mathrm{X}-13.766$ & 0.9789 \\
F8 & $160 \pm 15$ & 16.488 & 27.4 & $\mathrm{Q}=16.488 \mathrm{X}+30.179$ & 0.9825 \\
F9 & 272 & 32.143 & 46.58 & $\mathrm{Q}=32.143 \mathrm{X}+17.357$ & 0.9821 \\
F10 & 262 & 34.726 & 44.86 & $\mathrm{Q}=34.726 \mathrm{X}+10.357$ & 0.9855 \\
\hline
\end{tabular}


ratio of EC and PVP and amount of plasticizer as patches F5 and F6, respectively.

When the cumulative amount of drug released per unit area $\left(\mu \mathrm{g} / \mathrm{cm}^{2}\right)$ is plotted against time (h) in Figure 1, linear plots are obtained for all the patches. Therefore, the drug release from the patches followed zero-order kinetics. A linear relationship between $\%$ release and square root of time was found (Figure 2) as proposed by Higuchi's theory, indicating the diffusion controlled mechanism of drug release.

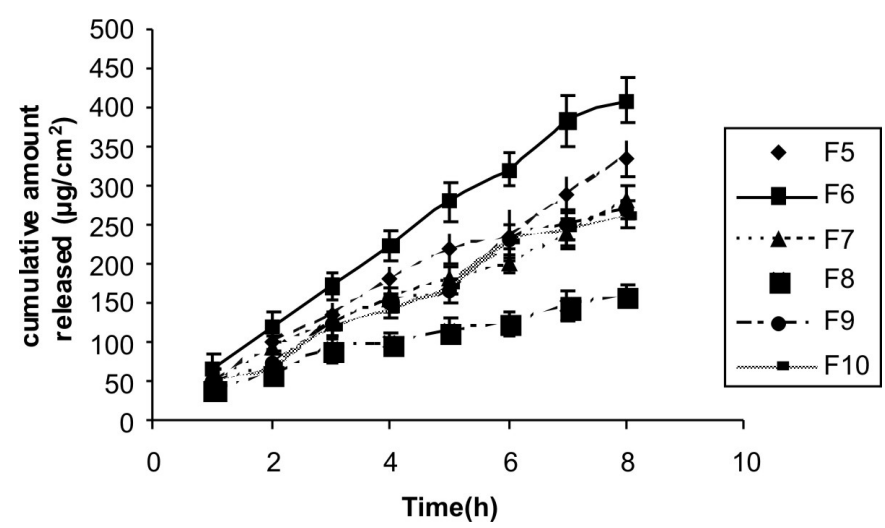

FIGURE 1 - Release profiles of glipizide from different matrix patches.

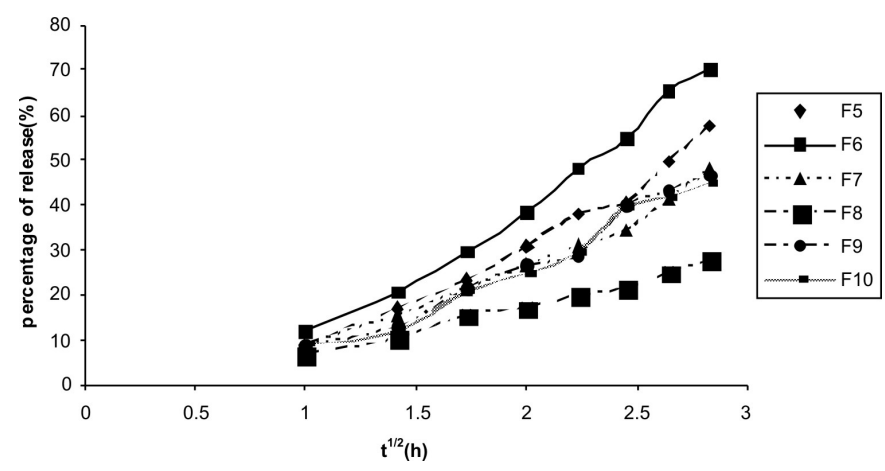

FIGURE 2 - Plots of percentage release versus $\mathrm{t}^{1 / 2}$.

\section{CONCLUSIONS}

DBP and ATBC were used as plasticizers. Plasticizers at a concentration of $20 \%$ and $30 \%$ of the total polymer weight were added. However, only $30 \%$ plasticizer patches were smooth and flexible whereas other patches were brittle and not manageable. The patches prepared from DBP were smooth and flexible, providing greater drug release than ATBC patches. DBP was therefore selected as a better plasticizer than ATBC. PVP at different concentrations was used for the patch where greater amounts of PVP were associated to higher drug release. However, $200 \mathrm{mg}$ PVP in the
F5 patch produced slightly lower release than the F6 patch. Considering all the factors such as original patch quality, quality of the patch piece after $8 \mathrm{~h}$ study, total cumulative $\%$ release after $8 \mathrm{~h}$, uniformity in release rate at hourly intervals and release profile, whether following diffusion controlled mechanisms and Higuchi modeling or otherwise, the final polymer patches underwent further studies for permeation, pharmacokinetic studies using suitable animal models etc. The ideal patch was F6 but the F5 patch may also be considered for permeation etc.

\section{ACKNOWLEDGEMENTS}

The authors are grateful to Sun Pharma, Dadra, for providing glipizide BP; Pharma-Signet Chemical Corporation, Mumbai for providing ethyl cellulose N 22; SISCO research Lab. Pvt. Ltd., Mumbai for providing polyvinyl pyrrolidone (K-30) IP; Qualigens Fine Chemicals, a division of Glaxo India, for providing dibutyl phthalate LR; N.F. Morflex, North California for providing ATBC. The authors also wish to thank Mr. Aniruddha Chandra for editing the manuscript.

\section{REFERENCES}

ARUNACHALAM, S.; GUNASEKARAN, S. Diabetic research in India and China today: From literature-based mapping to health-care policy. Curr. Sci., v.82, n.9, p.1086-1097, 2002.

BENNETT, N.; PAPICH, M. G.; HOENIG, M.; FETTMAN, M. J.; LAPPIN, M. R. Evaluation of transdermal application of glipizide in a pluronic lecithin gel to healthy cats. Am. $J$. Vet. Sci., v.66, n.4, p.581-588, 2005.

DAVIS, S. N.; GRANNER, D. K.; Insulin, oral hypoglycemic agents, and the pharmacotherapy of the endocrine pancreas. In: HARDMAN, J. G., LIMBERD, L. E. (Eds.). The Pharmacological basis of therapeutics. 9.ed. New York: McGraw-Hill, 1996. p.1487-1517

KULKARNI, R. V.; MUTALIK, S.; HIREMATH, D. Effect of plasticizers on the permeability and mechanical properties of Eudragit films for transdermal application. Ind. J. Pharm. Sci., v.64, n.1, p.28-31, 2002.

MOSQUERA, M. J.; CAL, S.; SOUTO, C.; CONCHEIRO, A.; MARTNEZ-PACHECO, R.; GMEZ-AMOZA, J. L. Effects of storage humidity on the mechanical, microstructural and drug release properties of hydroxypropyl cellulose-based hydrophilic matrix tablets. Drug Dev. Ind. Pharm., v.23, n.4, p.403-406, 1997. 
MUKHERJEE, B.; MAHAPATRA, S.; GUPTA, R.; PATRA, B.; TIWARI, A.; ARORA, P. A comparison between povidone-ethylcellulose and povidone-eudragit transdermal dexamethasone matrix patches based on in vitro skin permeation. Eur. J. Pharm. Biopharm., v.59, n.3, p.475483, 2005a.

MUKHERJEE, B.; KANUPRIYA, S.; MAHAPATRA, S.; DAS, S.; PATRA, B. Sorbitan monolaurate 20 as a potential skin permeation enhancer in transdermal patches. J. Appl. Res., v.5, n.1, p.96-108, 2005 b.

MUNDEN, B. J. GEORGE, H. D.; BANKER, G. S. Evaluation of polymeric materials. J. Pharm. Sci., v.53, n.4, p.395-401, 1964.

MUTALIK, S.; UDUPA, N. Transdermal delivery of glibenclamide and glipizide: in vitro permeation studies through mouse skin. Pharmazie, v.57, n.12, p.838-841, 2002.

MUTALIK, S.; UDUPA, N. Effect of some penetration enhancers on the permeation of glibenclamide and glipizide through mouse skin. Pharmazie, v.58, n.12, p.891-894, 2003.

MUTALIK, S.; UDUPA, N. Glibenclamide transdermal patches: physicochemical, pharmacodynamic, and pharmacokinetic evaluations. J. Pharm. Sci., v.93, n.6, p.1577-1594, 2004.
MUTALIK, S.; UDUPA, N. Formulation development, in vitro and in vivo evaluation of membrane controlled transdermal systems of glibenclamide. J. Pharm. Pharm. Sci., v.8, n.1, p.26-38, 2005.

MUTALIK, S.; UDUPA, N. Pharmacological evaluation of membrane moderated transdermal system of glipizide. Clin. Exp. Pharmacol. Physiol., v.33, n.1-2, p.17-26, 2006.

MUTALIK, S.; UDUPA, N.; KUMARB, S.; AGARWALA, S.; SUBRAMANIANA, G; RANJITH, A. K. Glipizide matrix transdermal systems for diabetes mellitus: Preparation, in vitro and preclinical studies. Life Sci., v.79, n.16, p.15681577, 20.

NOLTE, M. S.; KARAM, J. H. Pancreatic hormones and antidiabetic drugs. In: KATZUNG, B. G. (Ed.) Basis and clinical pharmacology. 8.ed. New York: Lange Medical Books/McGraw Hill, 2003. p.683-705.

TOJO, K.; VALIA, K. H.; CHOTANI, G.; CHIEN Y. W. Long-term permeation kinetics of estradiol IV: A theoretical approach to simultaneous skin permeation and bioconversion of estradiol esters. Drug Dev. Ind. Pharm., v.11, n.6, p.1175-1193, 1985.

Received for publication on $17^{\text {th }}$ February 2009 Accepted for publication on $24^{\text {th }}$ August 2009 